\title{
Why the Hebrew Bible Might Be All GreeK to Me: ON THE USE OF THE XENOPHONTIC CORPUS IN DISCUSSIONS OF BIBLICAL LITERATURE*
}

\author{
Christine Mitchell
}

"Parallelomania" abounds. ${ }^{1}$

I am not a historian, but a literary critic. I have no interest in using biblical texts as historical sources. But I know that many other people have a great deal of interest in doing so. If we are going to use these texts as historical sources, then I think we should be very clear about how they function as literature before we make any use of them as "historical" documents. ${ }^{2}$ However, I do not think that literary analysis of biblical

* I wish to thank the members of the Seminar for their comments and suggestions, especially Lester Grabbe and Ehud Ben Zvi. Any errors and omissions that remain are, of course, my own.

1. I wondered about providing citations for the title and for this sentence. In true Bakhtinian style, no citation would be required, because the speech of Robert P. Carroll ("Jewgreek Greekjew: The Hebrew Bible Is All Greek to Me. Reflections on the Problematics of Dating the Origins of the Bible in Relation to Contemporary Discussions of Biblical Historiography," in Did Moses Speak Attic? Jewish Historiography and Scripture in the Hellenistic Period [ed. Lester L. Grabbe; JSOTSup 317; ESHM 3; Sheffield: Sheffield Academic, 2001], 91-107), and Samuel Sandmel ("Parallelomania," JBL 81 [1962]: 1-13), respectively, has become my own, shaped by and shaping the rest of the text (and on Bakhtin having done this himself, see Michael Holquist (Dialogism: Bakhtin and his World [2d ed.; New Accents; London: Routledge, 2002], 188). Similarly, the Chronicler or Qohelet or Ben Sira would not see the need for me to make a citation - they would understand that surely my readers/hearers would be as well-versed in the appropriate literature as myself. But those readers in the early twenty-first century might have other terms for my non-footnoting behaviour (although hearers might not, and perhaps that says something about the milieu in which biblical authors worked).

2. Cf. Mario Liverani, "Memorandum on the Approach to Historiographic Texts," Or 42 (1973): 178-94. 
texts is only the first step, leading to "truer" historical analysis-I play the literary game for its own sake. But in order to do the work that I want to do with biblical texts, I need the historians: I need the historians to tell me about the social and historical context in which biblical texts were created; I need the historians to tell me about institutions, family life, religion, and power. And I would like the historians to be able to do so without getting trapped into the circular arguments endemic to biblical studies.

So, I will step outside the circle. I will bring in the outside element, the comparative element that both unsettles and clarifies, that gives us another way into the problem, that gives us perhaps an entirely different problem. In fact, I will bring in two outside elements: one is the Xenophontic corpus from the late classical/early Hellenistic world; the other is the discussion of genre theory. I will try to begin to develop a theory of genre that will work for an analysis of ancient texts; I will test this theory on one body of texts, the Xenophontic corpus; I will then apply it to selected biblical texts. By developing the genre theory, I hope to avoid simple "parallelomania." Eventually, I will arrive at some preliminary conclusions about biblical texts and historical writing. This entire study is both preliminary and programmatic - many of its assertions will need to be demonstrated more clearly in the future.

The genre theory that I will be working on will be based in the work of Mikhail Bakhtin. Form criticism is still the primary way of looking at genre in biblical studies, and Bakhtin's work is very useful in starting to look at other conceptions of genre. It is precisely because Bakhtin was working in the early to mid-part of the twentieth century that his work is so useful- he was well aware of and reactive to "form" criticism in its early manifestations in the critical world. His reactions (or his circle's) against Russian Formalism are helpful in formulating a non-formal theory of genre. Traditional form criticism, with its insistence on locating the original Sitz im Leben, actually hinders our understanding of biblical texts for historical or historiographical use. Although form criticism also originally insisted on the study of the transformation of the genre through time, ${ }^{3}$ form criticism as it has been practiced in the last part of the twentieth century has been consistent in looking at original social situation and context. A theory of genre that is flexible enough to analyze a biblical text diachronically is one that I hope to begin to develop in the following pages. I will try to show how it might be used in the analysis of biblical texts at the end of the present study. The full implications will

3. Cf. Joe Foley, "Form Criticism and Genre Theory," Language and Literature 4 (1995): 173-91 (179-80). 
have to be spelled out elsewhere; nonetheless, I think there is enough material at this point to make a beginning.

\section{Literary Genres}

One of the problems plaguing any work with Bakhtin and genre is that Bakhtin did not develop any abstract system of genres. In fact, Bakhtin rejected both systems and radical relativism. ${ }^{4}$ In the early work of the Bakhtin circle (exemplified by Medvedev's The Formal Method in Literary Scholarship, ${ }^{5}$ often the only work of the Bakhtin circle cited by genre theorists), there are programmatic comments about genre. However, in the works solely authored by Bakhtin there are analytical or applied comments on specific texts, with no general framework laid out. ${ }^{6}$ Although Bakhtin made comments about genre in many of his works, for anything close to a definable statement, we should turn to Problems of Dostoevsky's Poetics (hereafter PDP), "The Problem of Speech Genres" (hereafter "Speech"), and "The Problem of the Text" (hereafter "Text"). ${ }^{7}$

In $P D P$, Bakhtin begins his discussion of genre by suggesting that:

A literary genre, by its very nature, reflects the most stable, "eternal" tendencies in literature's development. Always preserved in a genre are undying elements of the archaic. True, these archaic elements are preserved in it only thanks to their constant renewal, which is to say, their contemporization. A genre is always the same and yet not the same, always old and new simultaneously. Genre is reborn and renewed at every new stage in the development of literature and in every individual work of a given genre. This constitutes the life of the genre. Therefore

4. Gary Saul Morson, "Bakhtin, Genres, and Temporality," NLH 22 (1991): 1071-92 (1073).

5. P. N. Medvedev and M. M. Bakhtin, The Formal Method in Literary Scholarship: A Critical Introduction to Sociological Poetics (trans. Albert J. Wehrle; Baltimore: The Johns Hopkins University Press, 1978).

6. Clive Thomson, “Bakhtin's 'Theory' of Genre," Studies in Twentieth Century Literature 9 (1984): 29-40 (33).

7. M. M. Bakhtin, Problems of Dostoevsky's Poetics (ed. and trans. Caryl Emerson; with an Introduction by Wayne Booth; Theory and History of Literature 8; Minneapolis: University of Minnesota Press, 1984); Bakhtin, "The Problem of Speech Genres," Speech Genres and Other Late Essays (trans. Vern W. McGee; ed. Caryl Emerson and Michael Holquist; University of Texas Press Slavic Series 8; Austin: University of Texas Press, 1986), 60-102; Bakhtin, "The Problem of the Text in Linguistics, Philology and the Human Sciences: An Experiment in Philosophical Analysis," Speech Genres and Other Late Essays (trans. Vern W. McGee; ed. Caryl Emerson and Michael Holquist; University of Texas Press Slavic Series 8; Austin: University of Texas Press, 1986), 103-31. 
even the archaic elements preserved in a genre are not dead but eternally alive; that is, archaic elements are capable of renewing themselves. A genre lives in the present, but always remembers its past, its beginning. Genre is a representative of creative memory in the process of literary development. ${ }^{8}$

I have quoted this passage at length because I think that there are several parts of it that should be explored in more detail, and that have relevance to the discussion of ancient genre. Bakhtin began his own commentary on this passage by describing his understanding of the sources of the novelistic genre: the coalescing of a variety of primary genres that all had their roots in classical antiquity. ${ }^{9}$ His discussion of these genres and their change over time and their eventual use in the rise of the novel is complex. But what might be of interest to us is that "history" or "historiography" is not one of the genres that he saw contributing to the novel. Perhaps this is because historiography is in itself a complex secondary genre, like the novel.

In PDP, Bakhtin's discussion of the development of genres comes with his discussion of the social conditions or formations that prompted or embodied the various generic mutations. ${ }^{10}$ The social context of genre formation is important. Its corollary is that the uniqueness of social context leads to uniqueness of genre. Evelyn Cobley points out that since Bakhtin saw genre as an unrepeatable event, genre groupings do not seem possible in his thought. ${ }^{11}$ For those writing about Bakhtin and genre, an important feature to keep in mind is that for Bakhtin, literary genres carry wisdom. They are forms of thinking. ${ }^{12}$ They have a life of their own; they have a memory. Genre is central to creative memory in that a genre remembers its history. An author can uncover hidden meanings in a genre and unlock those potential meanings. ${ }^{13}$ Tradition, normally seen as being restrictive, becomes a liberating force-respect for tradition allows the accumulated meanings of a genre to produce new

8. PDP, 106, emphases original.

9. Ibid., 106-37.

10. Ibid., 106-37.

11. Evelyn Cobley, "Mikhail Bakhtin's Place in Genre Theory," Genre 21 (1988): 321-38 (327); cf. Bakhtin, "Speech," 75; Bakhtin, “Text," 106, 127.

12. Morson, "Bakhtin," 1077.

13. Ronald D. LeBlanc, "A la recherche du genre perdu: Fielding, Gogol, and Bakhtin's Genre Memory," in Russian Subjects: Empire, Nation, and the Culture of the Golden Age (ed. Monika Greenleaf and Stephen Moeller-Sally; Studies in Russian Literature and Theory; Evanston, Ill.: Northwestern University Press, 1998), 101-22 (101, 117-18). Cf. Bakhtin, PDP, 106. 
texts and interpretations. ${ }^{14}$ Genres mediate, and are in a state of constant renewal. ${ }^{15}$ Bakhtin is useful also in reminding us that all genres are ideological. ${ }^{16}$ There is no such thing as a "neutral" genre. The construction, maintenance, mutation, transformation, and innovation of genre are shaped by ideological forces.

Form on its own is not a helpful criterion in determining genre. Although Bakhtin repeatedly emphasized the link between style and genre, ${ }^{17}$ it is very difficult (if not impossible) to distinguish between historiography ("true") and novella ("not-true") on the basis of form alone. ${ }^{18}$ Form criticism has usually only been concerned with context of production of the smallest rhetorical units, and we need to begin to look at the genre of the greater rhetorical units, that is, the book as a whole, and the relationship between the various types of speech in the book. ${ }^{19}$ Bakhtin noted that,

[P] rimary genres [i.e. small rhetorical units] are altered and assume a special character when they enter into complex ones. They lose their immediate relation to actual reality and to the real utterances of others... They enter into actual reality only via the novel as a whole, that is, as a literary-artistic event and not as everyday life... A one-sided orientation toward primary genres inevitably leads to a vulgarization of the entire problem. ${ }^{20}$

So, where should we start in our development of an understanding of ancient genre? Each "example" of a genre is in fact an innovation of that genre, retaining the generic memory of its forbears, but innovating at the same time as it re-uses or relies upon that generic memory. The precise contours of the text within its genre are shaped by the social and political

14. Morson, "Bakhtin," 1089.

15. Thomson, "Bakhtin's 'Theory' of Genre," 34-35.

16. M. M. Bakhtin, "Discourse in the Novel," in The Dialogic Imagination: Four Essays (trans. Caryl Emerson and Michael Holquist; ed. Michael Holquist; University of Texas Press Slavic Series 1; Austin: University of Texas Press, 1984), 259-422 (333-35).

17. E.g. Bakhtin, "Speech," 66.

18. Cf. Meir Sternberg, The Poetics of Biblical Narrative: Ideological Literature and the Drama of Reading (ISBL; Bloomington: Indiana University Press, 1985), 23-35, on this point.

19. Form criticism is changing, placing more emphasis upon the whole book rather than the individual units. See Marvin A. Sweeney and Ehud Ben Zvi, eds., The Changing Face of Form Criticism for the Twenty-First Century (Grand Rapids: Eerdmans, 2003); and for an example of such a different kind of form criticism, see Ehud Ben Zvi, Micah (FOTL 21B: Grand Rapids: Eerdmans, 2000).

20. Bakhtin, "Speech," 62, emphases added. 
exigencies of the author and his/her perceived addressees. This understanding of genre does not rely on a list of features; it is not descriptive or prescriptive. The genre of historiography, then, is a genreconstruct that serves one purpose for an author, another one for a reader, and another one for the historian. The stable features of the genre suggest to us that we can read the biblical or classical text with a certain amount of common sense and its truths will reveal themselves to us. However, the ever-changing features of the genre should suggest to us that such an understanding is fraught with danger. ${ }^{21}$ Our universe of meaning is very different from that of the authors of biblical or classical texts. To understand the functioning of the genre, we need to trace the history of the genre and its development, check for "genre memory," and try to develop a sense of the generic expectations that the author is trying to address, while perhaps at the same time innovating or overthrowing them.

\section{Xenophon's Works}

There are several good biographies of Xenophon available. ${ }^{22}$ However, as Sarah Pomeroy points out, they are generally based on Xenophon's own writings along with the account found in Diogenes Laertius (third century C.E.). ${ }^{23}$ There is enough explicit information in Xenophon's works for us to make some attempt to place Xenophon's life and career in context. Xenophon (born ca. 430 B.C.E.) was a young man at the end of Socrates' life, enlisted as a mercenary in the army of Cyrus the Younger (ca. 401 B.C.E.), and was thus away from Athens during Socrates' trial. He returned to Greece and was exiled by the Athenians for having favoured the Spartans (ca. 394 B.C.E.). ${ }^{24} \mathrm{He}$ spent most of the rest of his life on two country estates in the Peloponnese and Corinth (although the decree of exile was rescinded around 365 B.C.E.), and died sometime after 359 B.C.E. His books were probably written while in exile, quite possibly over an extended period of time. Many of his books probably reached their final form in the 360 s, perhaps even as late as 360

21. Cf. Yuri M. Lotman, Universe of the Mind: A Semiotic Theory of Culture (trans. Ann Shukman; with an Introduction by Umberto Eco; Bloomington: Indiana University Press, 1990), 271.

22. See, for example, J. K. Anderson, Xenophon (London: Duckworth, 1974); Edouard Delebecque, Essai sur la vie de Xénophon (Paris: Klincksieck, 1957); John Dillery, Xenophon and the History of His Times (London: Routledge, 1995).

23. Sarah B. Pomeroy, Xenophon Oeconomicus: A Social and Historical Commentary (Oxford: Clarendon, 1994), 1-2.

24. Pomeroy, Xenophon, 4. 
B.C.E. ${ }^{25}$ Pomeroy argues that Xenophon was probably of the highest class in Athens (his family was at least of the second-highest class), and thus had a wealthy and privileged upbringing. ${ }^{26}$ Certainly the focus in his works on leadership, gentleman-farming, hunting, and other such upperclass occupations would suggest this, if nothing else. As Pomeroy points out, since Xenophon did not found a philosophical school or have a circle of followers, there was little inclination to preserve biographical details about him in antiquity.

That Xenophon seems to have worked in relative isolation, drawing upon the works of his predecessors for inspiration but rarely upon the works of his contemporaries ${ }^{27}$ may be of some importance to us. The impact that Xenophon had upon his successors may be gauged by the fact that none of his works have been lost. As Joel Farber describes, if Xenophon's Cyropaedia (and Agesilaus) did not directly become a handbook for Hellenistic rulers (a possibility he does not discount), then it certainly prefigured many Hellenistic theories about kingship. It is certainly possible to see the Cyropaedia as a handbook used by Hellenistic rulers; Farber cites several authors who have, but also notes that there has not been enough work done on the Hellenistic theorists about kingship in order to make any direct connections. ${ }^{28}$

I suggested above that we should check for generic expectations that the ancient author might have had to address. One way into the question with respect to Xenophon and historiography can be found in M. J. Wheeldon's "True Stories." In this essay, he asks, "[W]hy did readers believe historians' accounts of the past when in many cases we know these accounts to have been fictitious? and how did this belief affect their evaluation of these texts as worthwhile objects?"29 He suggests that at least by the late Republican period the generic expectation of historiography would have been two-fold: historiography would have had (1) an account of the past as it was and (2) an authorial preface vouching for the

25. E.g. the Oeconomicus, cf. Pomeroy, Xenophon, 8; the Cyropaedia, cf. Debora Levine Gera, Xenophon's Cyropaedia: Style, Genre, and Literary Technique (Oxford Classical Monographs; Oxford: Clarendon, 1993), 23-25; the Hellenica, cf. Vivienne Gray, The Character of Xenophon's Hellenica (London: Duckworth, 1989), 1.

26. Pomeroy, Xenophon, 2.

27. Ibid., 9-10.

28. J. Joel Farber, "The Cyropaedia and Hellenistic Kingship," AJP 100 (1979): 497-514 (497-99).

29. M. J. Wheeldon, “True Stories': The Reception of Historiography in Antiquity," in History as Text: The Writing of Ancient History (ed. Averil Cameron; London: Duckworth, 1989), 36-63 (36). 
truth of the author's account of the past $\mathrm{t}^{30}$-features found already in Herodotus. Zola Marie Packman's analysis of the language of credulity and incredulity in Herodotus, Thucydides and Xenophon suggests that for Herodotus, incredulity on the part of characters within the Histories, and by implication the readers of the Histories, was the response to new and unfamiliar information, and that for Herodotus, the main problem he foresaw in his readers/hearers was their suspicion of evidence that did not conform with their pre-existing ideas. ${ }^{31}$ Herodotus did not foresee that readers/hearers would simply accept the incredible on his authority - this is in marked contrast to later historians, whose statement of authority was considered sufficient for credibility. ${ }^{32}$ His job, therefore, was not to eliminate erroneous information, but to make more information available. ${ }^{33}$ While Thucydides continued to use the same kind of language around the incredible to the same effect as Herodotus had, Xenophon did not. Packman notes that Xenophon did not seem to feel that there would be incredulity directed against him as a teller of the story, and suggests that the achievements of Herodotus and Thucydides allowed Xenophon not to have to plead for trust in his account. ${ }^{34}$ However, the analysis of Wheeldon shows us that in later antiquity some effort went into establishing the author's authority. Xenophon therefore appears as an anomaly, and further analysis is needed on this issue. By later antiquity, it was expected that historiography would be written in the third person, even when the author was a witness to or protagonist in the events recounted. ${ }^{35}$ In this respect, the genre-tradition that Xenophon shaped thus continued for many centuries after him.

Another way into the question of generic expectations is to examine Xenophon's works in relation to the works that he seems to have known and reflected. One feature that might be worthwhile to explore is his introductions. The Anabasis begins as follows: "Darius and Parysatis had two children; the elder was Artaxerxes and the younger was Cyrus. When Darius was sick and suspected that the end of his life was near, he wanted both of his children to be near him" (1.1.1). ${ }^{36}$ Now this beginning looks nothing like the beginning of Herotodus's or Thucydides' histories,

30. Wheeldon, "True Stories," 44-45.

31. Zola Marie Packman, "The Incredible and the Incredulous: The Vocabulary of Disbelief in Herodotus, Thucydides, and Xenophon," Hermes 119 (1991): 399414 (406).

32. Wheeldon, "True Stories," 62.

33. Packman, "Incredible," 406-7.

34. Ibid., 409.

35. Wheeldon, "True Stories," 45-46.

36. All translations from ancient sources are my own. 
both of which explicitly set out their reasons for writing their works (Hdt. 1.1; Thuc. 1.1). In fact, as Robert Fowler points out, the firstperson introduction (such as Herodotus's or Thucydides') is known for a number of fifth-century works; this introduction usually sets out the importance of the question or vouches for the reliability of the information..$^{37}$ Continued reading in the Anabasis makes it clear that a story set in the past is being related; the relationship of the teller of the story to the story events does not become immediately clear.

Turning to the Hellenica, we are confronted by a very different problem. The Hellenica begins as follows:

After this (meta de tauta), not many days later, Thymochares came from Athens with a few ships, and immediately the Spartans and the Athenians fought at sea again. The Spartans won under the leadership of Agesandridas. Shortly after this, Dorieus son of Diagoras sailed from Rhodes into the Hellespont at the beginning of winter... (1.1.1-2)

The chronology of winter and summer for military action is taken over from Thucydides, and the introductory meta de tauta presupposes an earlier story. This beginning sets up a generic expectation of Thucydidean historiography. Yet, as Vivienne Gray points out, this expectation is almost immediately refuted..$^{38}$ Turning to the Cyropaedia, we find a very clear introduction:

The consideration once occurred to us how many democracies have been overthrown by people wanting to be governed by any other means than democracy; again, how many monarchies and how many oligarchies before this have been abolished by the people... When we considered that Cyrus the Persian, who acquired for himself the obedience of a great many people... Since we believe this man to be worthy of wonder, we have examined who he was by birth... (1.1.1-6)

Similarly we find in the Memorabilia, "I have often wondered by what arguments those who indicted Socrates persuaded the Athenians that it was right for him to die for the polis..." (1.1.1); and in the Oeconomicus, "I once heard him discuss the subject of estate management in the following way" (1.1). The point, I think, should be clear: Xenophon knew how to frame an introduction, and if one was generally expected in historiography (as seems likely from the fifth-century sources), he could have provided it. Clearly he chose not to, so either the Anabasis and the Hellenica are not historiographies or they are, and Xenophon was

37. Robert L. Fowler, "Herodotos and his Contemporaries," Journal of Hellenic Studies 116 (1996): 62-87 (69).

38. Gray, Character, 2-6. 
playing with the generic expectation or perhaps drawing on generic memory. ${ }^{39}$ Playing with generic expectation seems to me to be most likely: Gray has outlined the various reasons why this might be so in the Hellenica, suggesting that Xenophon's generic model might have been Herodotus, not Thucydides (I think the implication would be that Xenophon deliberately set up the Hellenica in order to play between the two authors) $; 40$ and the introduction of the Anabasis seems to me to be not unlike the causal events described in Herodotus 1.1 (after the proem) or Herodotus's epic predecessor Homer in the Iliad (1.10ff.).

An index of the relationship between Xenophon and his predecessors is Xenophon's use of the term legetai, "it is said." In the Cyropaedia, it is used primarily in Books 1 and 8, those books in which Xenophon covers the same ground about Cyrus's life as had been covered previously by Herodotus and Ctesias. It is almost always used where there are competing versions to his story. An example of this is Cyrus's ancestry: about Cyrus's father, Xenophon says that he "is said (legetai) to have been Cambyses, king of the Persians" (1.2.1). This takes care of Herodotus, for whom Cambyses is the father, but not a king (Hdt. 1.107). It also takes care of Ctesias, for whom Cambyses is not the father $(\mathrm{FGrH}$ $90 \mathrm{~F}$ 66.3). ${ }^{41}$ Thus, it is not said by everyone. With regard to Cyrus's mother, Xenophon says that "it is generally agreed (homologeitai)" that it was Mandane, daughter of Astyages (1.2.1): this statement thus agrees with Herodotus (Hdt. 1.108) and disputes the position of Ctesias $(F G r H$ $688 \mathrm{~F} 9.1)$. Thus, it is not generally agreed. At the end of the work, in 8.6.19-20, we are told that Cyrus is said to have collected his army and gone off to campaign against the other nations he had not already conquered, as well as Egypt. ${ }^{42}$ Herodotus left the conquest of Egypt to Cyrus's son Cambyses (Hdt. 2.1), and Steven Hirsch has speculated that there may have been the accretion of traditions about the deeds of

39. Gray makes the suggestion that Xenophon's structure of the Hellenica is closer to the definition of history in Aristotle's Poetics (59a20-26) — a simple chronological reporting - than it is to the structuring devices in either Herodotus or Thucydides (Character, 178).

40. Ibid., 4-6.

41. If we can trust the account of Nicolaus of Damascus. Cf. Mark Toher, "On the Use of Nicolaus' Historical Fragments," Classical Antiquity 8 (1989): 159-72. The fragment can be found in F. Jacoby, Die Fragmente der griechischen Historiker (Leiden: Brill, 1923-57), abbreviated hereafter to $\mathrm{FGrH}$.

42. Bodil Due, The Cyropaedia: Xenophon's Aims and Methods (Aarhus: Aarhus University Press, 1989), 161, suggests that these subsequent campaigns are compressed in the narrative because of the focus on the "just war" of Cyrus against the Assyrian aggressor. 
Cyrus's successors to Cyrus himself, reflected in the Cyropaedia.$^{43}$ It is important to note that rather than simply reporting that these campaigns took place, Xenophon uses the word legetai, thus emphasizing the existence of those other accounts. Hirsch has suggested that the use (three times) of legetai in Cyr. 8.6.20-22 is contrary to Xenophon's normal practice and it indicates that Xenophon was only reporting something he had heard, a tradition, rather than simply stating it as a fact. ${ }^{44}$ I would note that of the 32 uses of legetai in the Cyropaedia, 25 are used by the narrator of a tradition about Cyrus, and these are found largely in Book 1 and Book $8 .{ }^{45}$ It is as if, by the use of legetai, Xenophon were saying that he knows his narrative opposes other texts, and he is thus both acknowledging that other positions exist and that his position opposes them. This ideological positioning within the text-continuum allows us to see the operation of genre: the Cyropaedia is the representation of one side of a dialogue, the dialogue being the favourite form of the Socratic philosophers, including Xenophon himself. The other side of the dialogue is implied, but not expressed.

When we look at Xenophon's use of legetai in the Anabasis and the Hellenica, as well as in the Memorabilia, we find many fewer uses, and used generally very differently. In the Anabasis, it is used almost exclusively to refer to mythical events or to proverbs (so in 1.2.8, 9, 13; $1.8 .6 ; 3.4 .11 ; 3.5 .15 ; 5.7 .7 ; 6.2 .1,2)$. The places where it is not are quite interesting $(1.2 .14 ; 1.8 .24,28 ; 2.6 .29)$, and are more like the uses in the Cyropaedia; I will explore its use in 1.8, the account of the death of Cyrus the Younger, as its use here is juxtaposed with Xenophon's only named source (in his entire corpus of work). In 1.8.24, we are told that in the final battle, Cyrus the Younger defeated the king's picked troops, and that "it is said (legetai) he killed with his own hand their commander Artagerses." This depiction of Cyrus the Younger's ability is quite consonant with the picture of him throughout the Anabasis. I would suggest that the use of this word here indicates that Xenophon knew of contrary versions, but chose not to present them. The support for this can be drawn from the death of Cyrus the Younger's favourite attendant: "It is said (legetai) that Artapatas, the most trusted of his staff-bearers, when he saw Cyrus fallen, leapt down from his horse to embrace him. And some say (hoi men phasi) that the king ordered someone to slay him, but

43. Steven W. Hirsch, The Friendship of the Barbarians: Xenophon and the Persian Empire (Hanover: University Press of New England, 1985), 79-80.

44. Hirsch, Friendship, 79-80.

45. Traditions about Cyrus: $1.2 .1(2 \times) ; 1.3 .4,15 ; 1.4 .25,26(2 \times), 27 ; 1.5 .1 ; 8.2 .9$, $13,15,18,19 ; 8.3 .26 ; 8.6 .19,20(2 \times)$; the other occurrences of legetai are 2.1.11; $4.2 .13,15 ; 4.5 .9 ; 5.2 .20 ; 7.3 .15$. 
others say (hoi $d^{\prime}$ ) that drawing his short sword he slew himself..." (1.8.28-29). I think what Xenophon is suggesting by the use of legetai is that there were those who disputed that Artapatas leapt down to embrace Cyrus; but the devotion displayed by Artapatas is appropriate for the depiction of Cyrus in the Anabasis. For Xenophon's purposes it does not matter how Artapatas died - either way shows the high worth of this slave, ${ }^{46}$ and so he can give two versions of the story (notably using phasi, not legetai). Thus it is precisely because he is not refuting another position that he can quote Ctesias (as a physician, not as a historian ${ }^{47}$ ) in 1.8.26 and 27. There are fewer uses of legetai in the Hellenica and the Memorabilia, and I believe they can be shown to follow the same general pattern as the Anabasis, although I will not argue it in detail here. Gray's recent article on the citations in the Hellenica and the Anabasis does deal with some of these issues. ${ }^{48}$ The disputatious use of legetai in An. 1.8, paralleling its use in the Cyropaedia, may indicate the irruption of another generic usage into the Anabasis, not unlikely when we consider that in many ways the depiction of Cyrus the Younger in the Anabasis and Cyrus in the Cyropaedia are similar. ${ }^{49}$

When we compare Xenophon's use of legetai with Herodotus's and Thucydides', the pattern is striking. Thucydides makes use of the term in much the same way as Xenophon in the Anabasis, Hellenica, and Memorabilia, in referring to the legendary past, oracular answer, and to the inner thoughts of persons whose actions are then reported. The disputatious use of the Cyropaedia is not paralleled. Herodotus's use of the term is very frequent (over one hundred occurrences). He seems to have used the term to present material that he did not necessarily believe to be true, but that should be presented nonetheless (and which could possibly be true). An example might be about the funeral practices of the Magi: "I know and can say in truth these [previous] things about them; however, it is said (legetai) secretly and not clearly, thus about the dead..." (1.140.1). This should be contrasted with Herodotus's common formulation for source citation, legousi (hoi), which while occasionally used as functionally equivalent to legetai, is more usually paired with a specific subject (the "locals," the "Egyptians," etc.), and which occurs twice as many times as legetai. Detlev Fehling's well-known work on

46. Vivienne Gray, "Interventions and Citations in Xenophon, Hellenica and Anabasis," CQ 53 (2003): 111-23 (121).

47. Cf. Gray, "Interventions," 117.

48. Ibid.

49. That one was a model for the other in Xenophon's works is reasonably clear; which way the modelling went is much-discussed; cf. Gera, Xenophon's Cyropaedia, 11. 
Herodotus's sources focuses primarily on the formula legousi,${ }^{50}$ and he could conclude that there were three main principles behind the use of Herodotus's source citations: the principle of citing the obvious source, the principle of maintaining credibility, and the principle of regard for party bias. ${ }^{51} \mathrm{He}$ also concluded that Herodotus could invent a source citation when it suited his literary purposes - a conclusion that has led Fehling's work to be used (or described) as questioning the usefulness of Herodotus for historical research..$^{52}$ This is a debate I do not want to enter here, except to note that the debate runs exactly parallel to the one this Seminar is engaged in, and that Fowler's comment about Herodotus's vs. Thucydides' authorial voice might be pertinent here: "The absence of [voice] markers is no guarantee of objectivity; by the same token, a plethora of markers does not imply an historian who is allowing his own personality to get in the way of his job." ${ }_{53}$ However, I would suggest that the use of legetai is probably part and parcel with Herodotus's anxiety about incredulity that I mentioned above. I should make it clear here that I am not discussing this term in hopes of deriving something about historical methodology (perhaps the most obvious result of the discussion), but rather generic expectations.

When we tie the analysis of legetai together with Packman's analysis of the vocabulary of incredulity, it becomes clear that Xenophon was aware of the generic expectations of using legetai when he wrote (at least) the Anabasis and the Hellenica, although he chose to innovate within the genre by occasionally using the term to cast doubt on the versions he was not presenting. Innovation rather than imitation is in fact typical of Xenophon's works; Gray has analyzed his relationship with wisdom literature in some detail. ${ }^{54}$

The use of legetai also brings up another feature of Xenophon's relationship to his sources: Bernhard Huss notes that, in his works, Xenophon does not merely quote previous authors, but uses those ele-

50. Fowler ("Herodotos," 77) notes that Herodotus uses a variety of terms to denote his relationship with his sources, and that this seems to have been original to him.

51. Detlev Fehling, Herodotus and his "Sources": Citation, Invention and Narrative Art (trans. J. G. Howie; ARCA 21; Leeds: Francis Cairns, 1989), 257.

52. Fehling, Herodotus, 258. For a balanced view of his arguments, see Fowler, "Herodotos," 80-85.

53. Fowler, "Herodotos," 76.

54. Vivienne Gray, The Framing of Socrates: The Literary Interpretation of Xenophon's Memorabilia (Hermes Einzelschriften 79; Stuttgart: Franz Steiner, 1998); Gray, "Xenophon's Symposion: The Display of Wisdom," Hermes 120 (1992): 58-75. 
ments for his own purposes to create his own literary work. ${ }^{55}$ Huss makes this note about the Symposium, but Due, James Tatum, and Deborah Levine Gera have made similar observations about the Cyropaedia: Tatum's analysis of the relationship between Xenophon's account of Croesus and Cyrus and Herodotus's is particularly helpful in this regard; although Gera disputes almost every part of this analysis, I think it is the most convincing one. ${ }^{56}$

Finally, the use of legetai brings up the question of genre again for Xenophon's three long works. I have shown how legetai was used by Xenophon in the Anabasis and the Hellenica in manners consistent with or in conversation with previous historiographic works (Herodotus and Thucydides). I have also indicated how Xenophon's use of legetai in the Cyropaedia is not consistent with the use in Herodotus and Thucydides, and is in fact an almost disputatious use, indicating where the opposing side of a dialogue has been omitted. This of course is much more consonant with the Socratic dialogue, as I indicated. The Cyropaedia has had an interesting history in terms of genre-reception (the discussions in Due, Gera, and Tatum give an outline); but for our purposes what is most interesting is that both historians and political philosophers in the academy today use this work. I refer to the works of Hirsch and Christopher Nadon, respectively. ${ }^{57}$ It is not just that a work can simultaneously belong to more than one genre (although that is one possibility); it is that a work can bring out the genre memory carried within the genre.

Before turning to a discussion of biblical literary genres, we need to give some attention to that other facet of a Bakhtinian understanding of genre: social situation and context. Xenophon worked in relative literary isolation: he does not seem to have been current with fourth-century literature, preferring instead to innovate from fifth-century literature. $\mathrm{He}$ was a citizen-soldier, then mercenary, then country gentleman. He founded no school, had no disciples, and yet all of his works have been preserved. Much has been made (both in antiquity and today) of the perceived rivalry between Xenophon and Plato, although the rivalry may

55. Bernhard Huss, "The Dancing Sokrates and the Laughing Xenophon, or the Other Symposium," AJP 120 (1999): 381-409 (382).

56. James Tatum, Xenophon's Imperial Fiction: On The Education of Cyrus (Princeton: Princeton University Press, 1989), 147-59; Gera, Xenophon's Cyropaedia, 265-78.

57. Hirsch, Friendship; Hirsch, "1001 Iranian Nights: History and Fiction in Xenophon's Cyropaedia," in The Greek Historians: Literature and History (ed. Michael Jameson; Saratoga: ANMA Libri, 1985), 65-85; Christopher Nadon, Xenophon's Prince: Republic and Empire in the Cyropaedia (Berkeley: University of California Press, 2001). 
be created by us, the readers of the texts, placing them in dialogic relationship. That they did know each other's works is fairly clear: Xenophon certainly made use of Plato's Symposium while writing his own, and Plato commented in somewhat a derogatory fashion about Xenophon's depiction of Cyrus in the Laws (694c); Tatum suggests that in two parts of the Laws (643e-644a; 693e-696b), Plato was responding in detail to the arguments of Xenophon in the Cyropaedia. ${ }^{58}$ I think what is important for us to note about Xenophon's context is his relative isolation. He innovated because he had the freedom to do so.

\section{Biblical Literary Genres}

In the biblical tradition, very rarely do we get anything like a statement of the purpose of the book. One text that does provide such a statement is Qohelet (1:12-18); of course, this book is traditionally dated late by scholars, and is often held up as one with clear marks of Hellenistic philosophic influence. However, as Michael Fox points out, the most noteworthy parallels between Qohelet and Hellenistic philosophy may be the ones that are least easy to prove. ${ }^{59}$ Here again we have a rebellion against the vague search for Hellenistic parallels. Perhaps the genre route might be more fruitful. I shall take a small example, ignoring for reasons of space the wider literature on ancient Near Eastern wisdom. The introduction to Qohelet is really a double one: first a poetic statement of the argument preceded by a short introduction to the speaker and the theme of the book (1:1-11), and then a prose statement by the (implied) author about his reasons for his work, in which he quotes (or creates) two proverbs (1:12-18). As I noted, this second introduction is really quite unusual for a biblical text. The entire introduction, however, bears close examination in terms of its generic relationship. The poetic statement of the argument seems to be patterned formally on texts like Prov 1 (and both Ben Sira and the Wisdom of Solomon continued to use that generic form). It sets up the expectation of a certain kind of work. However, just as Xenophon's Hellenica played with the form of Thucydides' History, so the beginning of Qohelet begins to overturn generic expectation. Instead of a panegyric to the value of wisdom, we have the opposite.

58. Huss, "Dancing," 381-82. Whether Plato actually bothered to try to understand Xenophon's point is a question open for debate. See Tatum, Xenophon's, 38-41, 225-30, for this discussion. See Gera, Xenophon 's Cyropaedia, 12-13, for a discussion of the ancient sources on this "rivalry."

59. Michael V. Fox, A Time to Tear Down and A Time to Build Up: A Rereading of Ecclesiastes (Grand Rapids: Eerdmans, 1999), 8. 
Instead of the panegyric leading into a collection of proverbs, we have the non-panegyric leading into the (implied) author's declaration of the origins of his work. So is the book wisdom? Yes, it is - it is playing within the genre of wisdom literature. Removed from the generic expectations, the book would make no sense at all.

Finally, I reach historiography. Since in my discussion of Xenophon's works I discussed the introductions to the works as part of generic expectations, I will do the same here. I will use another series of small examples here, resisting the temptation to look at the DtH, since where the "beginning" of the DtH might be is not entirely clear to me. Ezra begins quite simply: "In the first year of Cyrus, the king of Persia, in order to fulfill the word of Yhwh from the mouth of Jeremiah, Yhwh stirred up the spirit of Cyrus, the king of Persia..." (1.1). Here is where I bring in the diachronic aspect of genre. To readers today, this introduction looks like "historiography": it gives a date and an action. The influence of the divine on the action is not, of course, something that we would consider appropriate history writing, but we are perfectly willing to make allowances for the practices of people in another time and place. ${ }^{60}$ It looks like historiography to us precisely because we have been schooled in the generic understanding of Thucydides as to what historiography should look like. It is so "common-sense" to us that we cannot conceive of it any other way. But it does not look like the introductions to any of the "historical" books elsewhere in the Hebrew Bible. It does look like the introduction to Esther: "It happened in the days of Ahasuerus, that Ahasuerus who was ruling from India to Cush, over one hundred and twenty seven provinces" (Esth 1.1). And it does look like the introduction to Ruth: "It happened in the days of the judges that there was a famine in the land" (Ruth 1.1). The difference is that Ezra has that definite temporal marker, the first year of Cyrus. So, then, are Esther and Ruth playing with the generic expectations of historiography? But then what about Daniel: "In the third year of the rule of Jehoiakim, king of Judah, Nebuchadnezzar, king of Babylon, came to Jerusalem and attacked it" (Dan 1.1)? Is Daniel also playing with the generic expectations of historiography? And of course, dating events by any means does not mean that a text is historiographic, or even that this is a formal marker of historiography (e.g. Isa 6.1: "In the year King Uzziah died, I saw the Lord sitting upon a throne...."). Form here is our enemy, as Sternberg pointed out (above). But looking at generic

60. On Xenophon's innovation with respect to the impact of the divine in history, see Frances Skoczylas Pownall, "Condemnation of the Impious in Xenophon's Hellenica," HTR 91 (1998): 251-77. 
expectations and genre memory may help us out. Ezra(-Nehemiah) may be a generic innovation, working within yet at the same time expanding and renewing an already-existing genre of historiography. Or it may be part of entirely different generic horizon, operating within a different set of generic expectations.

If we consider the texts that are often designated as the "Primary History" as historiography (for the sake of argument), then we can see a certain set of generic expectations when we compare those texts to Chronicles, which quotes or uses those texts extensively. ${ }^{61}$ To take one limited example, it is reasonably clear that some kind of reference to books that contained more information was required for a historiography. We can see this simply by the fact that the Chronicler's references to these books almost always occur at exactly the same point in the story as they do in Kings; it is simply the name of the book that has been changed. H. G. M. Williamson points out that there are two places in Chronicles where this pattern is not followed: $1 \mathrm{Chr}$ 29:29 and $2 \mathrm{Chr}$ 35:26-27. ${ }^{62}$ The fact that such a reference is created for $1 \mathrm{Chr} 29: 29$, when no such reference occurs in the Samuel-Kings accounts of David's reign, suggests very strongly that this was the generic expectation, made consistent throughout Chronicles. Perhaps references such as these serve the same function as legetai does. Which function of legetai is open for discussion: the reporting of additional information of Herodotus, the reporting of proverbial or unattested information of Thucydides, or the disputatious use of the Cyropaedia? I do not want to pick one for now, although if pressed, I would opt for the disputatious use, given the transformative, dialogic structure of Chronicles as a whole. ${ }^{63}$

Another example may be made of the genealogies. The fact that Chronicles begins with nine chapters of largely genealogical information should be a clue of some importance. The books of the Torah all contain genealogical information to a greater or lesser extent; Genesis (for example), punctuates the story with genealogies. Perhaps the generic

61. Even if one subscribes to Graeme Auld's theory of a common source behind both Samuel-Kings and Chronicles (and I do not), the fact that the Chronicler used some previous source that looks a lot like Samuel-Kings cannot be denied. Cf. A. Graeme Auld, Kings Without Privilege: David and Moses in the Story of the Bible's Kings (Edinburgh: T. \& T. Clark, 1994).

62. H. G. M. Williamson, "The Death of Josiah and the Continuing Development of the Deuteronomic History," VT 32 (1982): 242-48 (244-45). Although this is very interesting for the textual development of Samuel, Kings, and Chronicles, it does not bear on the question of generic expectations.

63. Christine Mitchell, "Transformations of Meaning: The Accession of Solomon in Chronicles," JHS 4 (2002) <http://purl.org/jhs >. 
expectation the Chronicler is playing with here is the placement of the genealogies: rather than punctuating the narrative, they are grouped together at the beginning of the book. The function of the genealogies at the beginning of Ionian historiographic works has been studied as it might relate to Chronicles. ${ }^{64}$

Certainly, Chronicles is made up of a wide variety of speech genres: it includes genealogies, lists, hymns, prayers, large portions of other works, levitical speeches, and so on. These are the speech genres that Bakhtin would describe as being "primary," that is, the simplest kind. They may be imitations of texts that arise in a "life setting," but they are not related to reality except in an artistic way. The novel, as a complex secondary speech genre, is made up of primary genres. I wondered above if historiography would similarly be a complex secondary speech genre. Whether or not it is "historiography" (although we are assuming that for the sake of the argument), Chronicles is a complex of speech genres. So too, of course, are books like Genesis, Exodus, or Judges. Thus, the issue would be how can we tell one complex secondary speech genre from another? Or, how can we tell a novel apart from historiography? I argued in a previous work that because Chronicles looks like a novel, we can use Bakhtinian methods to analyze it. ${ }^{65}$ In that work I was not interested in telling a novel and historiography apart.

A final example from Chronicles might be the beginning of the narrative proper in $1 \mathrm{Chr} 10$. The narrative begins mid-stream, as it were, beginning at the end of a story that is already clearly presupposed by the rest of the book. In this way the action of the book begins no differently from a book such as Deuteronomy. Deuteronomy includes a narrative recapitulation of the "back-story" (Deut 1-4); Chronicles alludes to the back-story without ever making it explicit. ${ }^{66}$ The expectation of the genre did not include a firmly and absolutely dated beginning point for the action. In this way, of course, Chronicles is not unlike either the Anabasis or (especially) the Hellenica, by beginning the story with the presupposition that the back-story is already known to the readers/hearers.

If these markers of generic expectations of what we are calling "historiography" are reliable, then Ezra is an innovation within the genreand it may not be the only example, and depending on the relative dating

64. Gary N. Knoppers, “Greek Historiography and the Chronicler's History: A Reexamination," JBL 122 (2003): 627-50.

65. Christine Mitchell, "The Dialogism of Chronicles," in The Chronicler as Author: Studies in Text and Texture (ed. M. Patrick Graham and Steven L. McKenzie; JSOTSup 238; Sheffield: Sheffield Academic, 1999), 311-26 (313-14).

66. Jonah 1.1 also begins in the middle of the story. However, Jonah is also playing with other generic conventions. 
of other Persian and Hellenistic period books, may not be such an innovation after all. However, it is an innovation in just the "right" kind of ways for us to understand it as historiography today. What kinds of social contexts or social situations might have led to this change? When, for example, would precisely marking the time of the beginning of the action have become so important? When would making a clear introduction to the action of the story have become so important, rather than leaving it implied or spelled out within the story itself? Clearly, the innovation of Chronicles, grouping all the genealogies together at the beginning, was one that did not endure, as Ezra-Nehemiah has genealogies and lists scattered in various places. However, the question of sources or additional material is one that Ezra (and Nehemiah) deals with differently than Chronicles had. Rather than referring the reader to another book (and thus alluding to material that is omitted from the account), Ezra includes the material by quoting letters and memoirs. The Chronicler was confident enough in his/her own authority as author that such other material could be omitted. Perhaps for Ezra we are looking at an author who is not certain about his/her own authority. Perhaps we are looking at an individual, working in relative isolation, creating a text from texts (written and oral) about the founders of the post-exilic Yehud community. ${ }^{67}$ The text works within a certain generic expectation, and can therefore take on the power of that expectation. The power of the genre now becomes apparent. Whether or not we want to call this genre "historiography" is beside the point.

\section{Biblical Historiography-A Conclusion?}

Having spent a great deal of time outlining my understanding of genre and how this relates to the Xenophontic corpus raises the question of the use of Xenophon for biblical studies. The easiest thing to do would be to simply compare the biblical texts to texts from the Xenophontic corpus. Certainly this could be done (and in certain cases has been): EzraNehemiah to the Anabasis, Kings to the Hellenica, Ben Sira to the Agesilaus, Chronicles to the Cyropaedia, Proverbs to the Socratic works (Oeconomicus, Memorabilia, Symposium). ${ }^{68}$ But what would that really

67. Lester L. Grabbe, Ezra-Nehemiah (Old Testament Readings; London: Routledge, 1998), 187-89.

68. Thomas R. Lee, Studies in the Form of Sirach 44-50 (SBLDS 75; Atlanta: Scholars Press, 1986); Christine Mitchell, "Bakhtin and the Ideal Ruler in 1-2 Chronicles and the Cyropaedia," in Bakhtin, the Russian Formalists and Ancient Narrative (ed. R. B. Branham; Ancient Narrative Supplementum 2; Eelde, The Netherlands: Barkhuis/Library of the University of Groningen, forthcoming). 
tell us? Besides indulging in "parallelomania," would this really tell us anything about biblical genre? More importantly for our purposes here, would this really tell us anything about the expectations of historiography for the biblical authors? In a way, these comparisons are synchronic - they look at the two comparative texts in isolation from their generic development, presupposing a definition of a genre (like encomium or memoir) that can never change. More fruitful, in my opinion, although built on the synchronic studies, are the possibilities of studying the operation of a genre through time. In this essay I have attempted to give a few hints of what this kind of study might look like, and what it might be able to produce. Further implications and analysis would still need to be worked out.

At the beginning of this study I spent some time expounding upon a Bakhtinian understanding of genre: eternal, stable, yet ever-changing and ever-new, shaped by social context and ideological forces. What are the implications then for this understanding of genre for the study of ancient historiography (i.e. the writing of history)? The biblical authors did not even know the term. It was a still-new term to Xenophon, who nonetheless went about innovating the genre to suit his purposes. In one way, this understanding is a bit disappointing: we cannot really know what the biblical authors and their audiences thought about the genre of historiography, at least until we get well into the Hellenistic period. However, this understanding of genre also gives us the freedom to use texts that look like historiography to us as historiographical. In fact, given our own social situated-ness and context, can we use them any other way? ${ }^{69}$ Historiography is potentially one of the most powerful genres because ultimately a historiographic work is telling the story of some individual or group's self-understanding. If the readers/hearers of the work identify with this self-understanding, then they will approve of the use of the genre. If the readers/hearers do not identify with this self-understanding, then they will disapprove of the use of the genre. The operation of the power of historiography in the biblical and Hellenistic worlds perhaps would be a rewarding issue to explore more fully.

69. Cf. Bernard C. Lategan, "Questing or Sense-Making? Some Thoughts on the Nature of Historiography," BibInt 11 (2003): 588-601. Lategan points out that our "sense-making operation" is secondary, that is, the biblical author has performed a previous sense-making operation; but he affirms the use of biblical sources for historical readings (pp. 597-98). 